\title{
The Viewer as Producer: British and Canadian Feminists reading Prudence Heward's "Women"
}

\section{Lynne Pearce}

Volume 25, numéro 1-2, 1998

Producing Women

Ces femmes qui produisent ...

URI : https://id.erudit.org/iderudit/1071617ar

DOI : https://doi.org/10.7202/1071617ar

Aller au sommaire du numéro

\section{Éditeur(s)}

UAAC-AAUC (University Art Association of Canada | Association d'art des universités du Canada)

\section{ISSN}

0315-9906 (imprimé)

1918-4778 (numérique)

Découvrir la revue

Citer cet article

Pearce, L. (1998). The Viewer as Producer: British and Canadian Feminists reading Prudence Heward's "Women". RACAR : Revue d'art canadienne / Canadian Art Review, 25(1-2), 94-102. https://doi.org/10.7202/1071617ar

\section{Résumé de l'article}

S'appuyant sur une recherche entreprise dans le cadre d'un projet plus large sur les processus et les pratiques de lectures féministes, cette étude examine les façons dont la lectrice/l'observatrice féministe devient une participante active dans la production du texte. Deux tableaux de l'artiste montréalaise Prudence Heward, Rollande (1929) et Jeune fille à la fenêtre (1941), se retrouvent au centre de cette étude. La production d'Heward comprend de nombreuses études de femmes, dont plus d'une sont " marquées » en termes d'identité nationale et ethnique et pour cette raison qu'elles deviennent d'excellents " textes " grâce auxquels l'observatrice féministe actuelle peut reconnaître les enjeux de l'identité sexuelle, de l'origine ethnique et coloniale dans ses propres réactions et dans sa lecture des textes.

Pour cette recherche, j'ai invité cinq groupes de féministes, originaires de Grande-Bretagne et du Canada, à réfléchir sur leur propres réactions face aux tableaux, à en faire part dans un questionnaire écrit et à en débattre dans des discussions de groupe. Cette enquête s'intéresse en particulier à la façon dont les observatrices ont exprimé leurs rapports complexes et souvent contradictoires avec le " texte ", grâce à une série de ce que j’ai désigné sous les termes de « l'autre textuel ». Alors que cette altérité textuelle pouvait être considérée comme la figure de la femme représentée dans le tableau (vue soit comme " un vrai modèle vivant ", ou soit comme un " modèle fictif " mais tout de même comme un sujet existentiel), cette dernière était très souvent configurée comme un ensemble complètement désincarné de sentiments, de souvenirs et de discours qui ont leurs origines dans la vie professionnelle et personnelle de l'observatrice.
Tous droits réservés (C) UAAC-AAUC (University Art Association of Canada | Association d'art des universités du Canada), 2001
Ce document est protégé par la loi sur le droit d'auteur. L’utilisation des services d'Érudit (y compris la reproduction) est assujettie à sa politique d'utilisation que vous pouvez consulter en ligne.

https://apropos.erudit.org/fr/usagers/politique-dutilisation/ 


\title{
The Viewer as Producer: British and Canadian Feminists reading Prudence Heward's "Women"
}

\author{
Lynne Pearce, Lancaster University, U.K.
}

$S^{R k w}$ 'appuyant sur une recherche entreprise dans le cadre d'un projet plus large sur les processus et les pratiques de lectures féministes, cette étude examine les façons dont la lectrice/ l'observatrice féministe devient une participante active dans la production du texte. Deux tableaux de l'artiste montréalaise Prudence Heward, Rollonde (1929) et Jeune fille à la fenêtre (1941), se retrouvent au centre de cette étude. La production d'Heward comprend de nombreuses études de femmes, dont plus d'une sont « marquées » en termes d'identité nationale et ethnique et pour cette raison qu'elles deviennent d'excellents « textes » grâce auxquels l'observatrice féministe actuelle peut reconnaître les enjeux de l'identité sexuelle, de l'origine ethnique et coloniale dans ses propres réactions et dans sa lecture des textes.

Pour cette recherche, j'ai invité cinq groupes de féministes, originaires de Grande-Bretagne et du Canada, à réfléchir sur leur propres réactions face aux tableaux, à en faire part dans un questionnaire écrit et à en débattre dans des discussions de groupe. Cette enquête s'intéresse en particulier à la façon dont les observatrices ont exprimé leurs rapports complexes et souvent contradictoires avec le " texte », grâce à une série de ce que j'ai désigné sous les termes de «l'autre textuel ». Alors que cette altérité textuelle pouvait être considérée comme la figure de la femme représentée dans le tableau (vue soit comme « un vrai modèle vivant», ou soit comme un "modèle fictif » mais tout de même comme un sujet existentiel), cette dernière etait très souvent configurée comme un ensemble complètement désincarné de sentiments, de souvenirs et de discours qui ont leurs origines dans la vie professionnelle et personnelle de l'observatrice.
$\mathrm{P}$ rudence Heward (1896-1947) was one of a group of women artists from Montréal associated with the Beaver Hill Hall Group (1920-21). Although a few of Heward's paintings (for example, Rollande, 1929: see fig. 1) have achieved iconic status within the national collections, her work in general - like that of many of her female contemporaries - is still in the process of being recovered from the margins of Canadian art history. ${ }^{1}$

This essay, however, focuses not on Heward "as producer," nor on her unique and powerful representations of the female subject per se, but on how five groups of feminist readers/ viewers from Britain and Canada negotiated their relationship to her work. In orher words, it shifts the "site of production" away from the artist, and the cultural/historical context in which she worked, to the space/place in which her work is reproduced. In theoretical and political terms, this perspective challenges the problematic polarization of (active) production and (passive) consumption and regards the "creation" of art as a profoundly dialogic and situated process in which artist, text and producer are continually engaged.

The material on which this discussion is based derives from a small "reader-survey" undertaken for my book, Feminism and the Politics of Reading. ${ }^{2}$ In the chapter entitled "Emotion/Reading/Politics" I used the responses of my various groups of feminist readers to explore the ways in which the (broadly) "personal" and the (broadly) "political" are held in uneasy tension (not least in being "artificially separated out") in the reading/viewing process. Two of Heward's paintings, Rollande (1929) and Girl at a Window (1941) (see fig. 2) were amongst the texts (visual and
Figure I. Prudence Heward, Rollande, 1929. Oil on canvas, $139.9 \times 101.7 \mathrm{~cm}$. National Gallery of Canada, Ottawa (Photo: National Gallery of Canada, Ottawa).

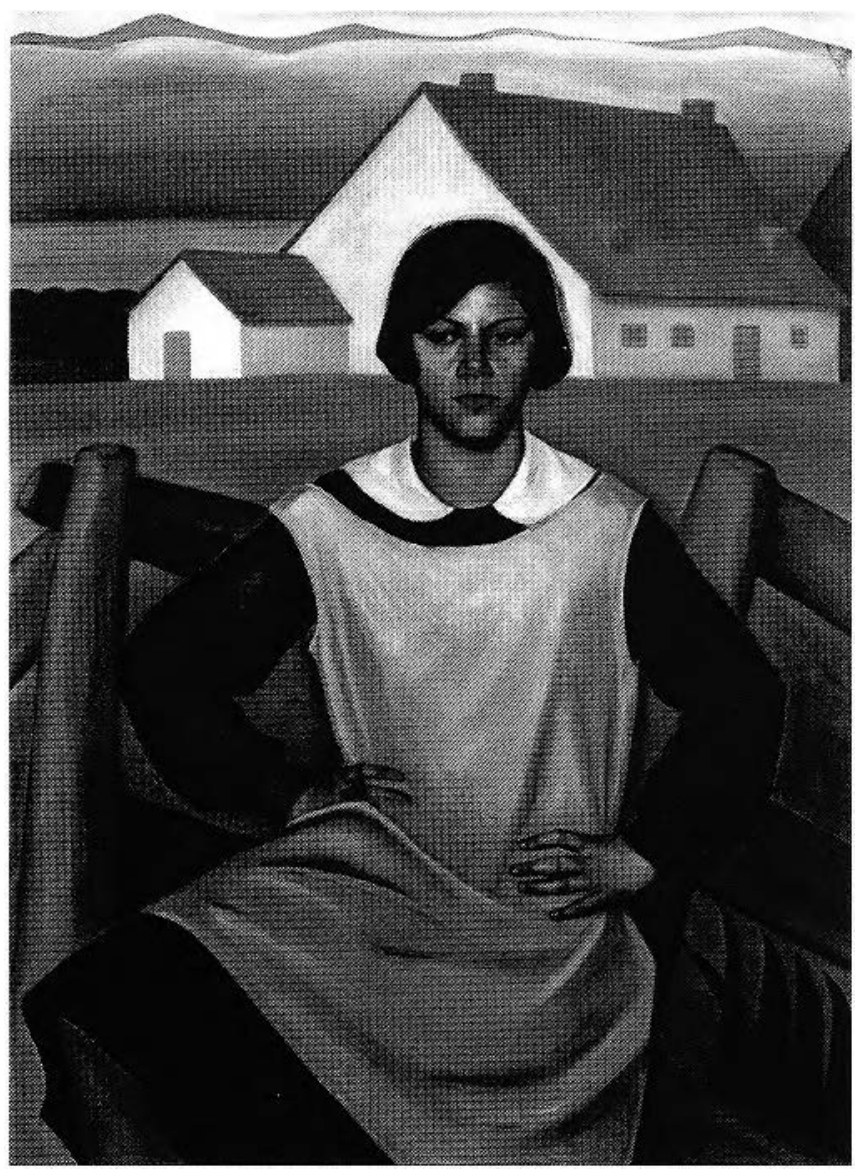


Figure 2. Prudence Heward, Girl at a Window, 1941. Oil on canvas, $86.4 \times 91.5 \mathrm{~cm}$. Art Gallery of Windsor, Ontario (Photo: Collection of the Art Gallery of Windsor. Given in memory of the artist and her sister by the Estate of Gladys S. Nares, 1981).

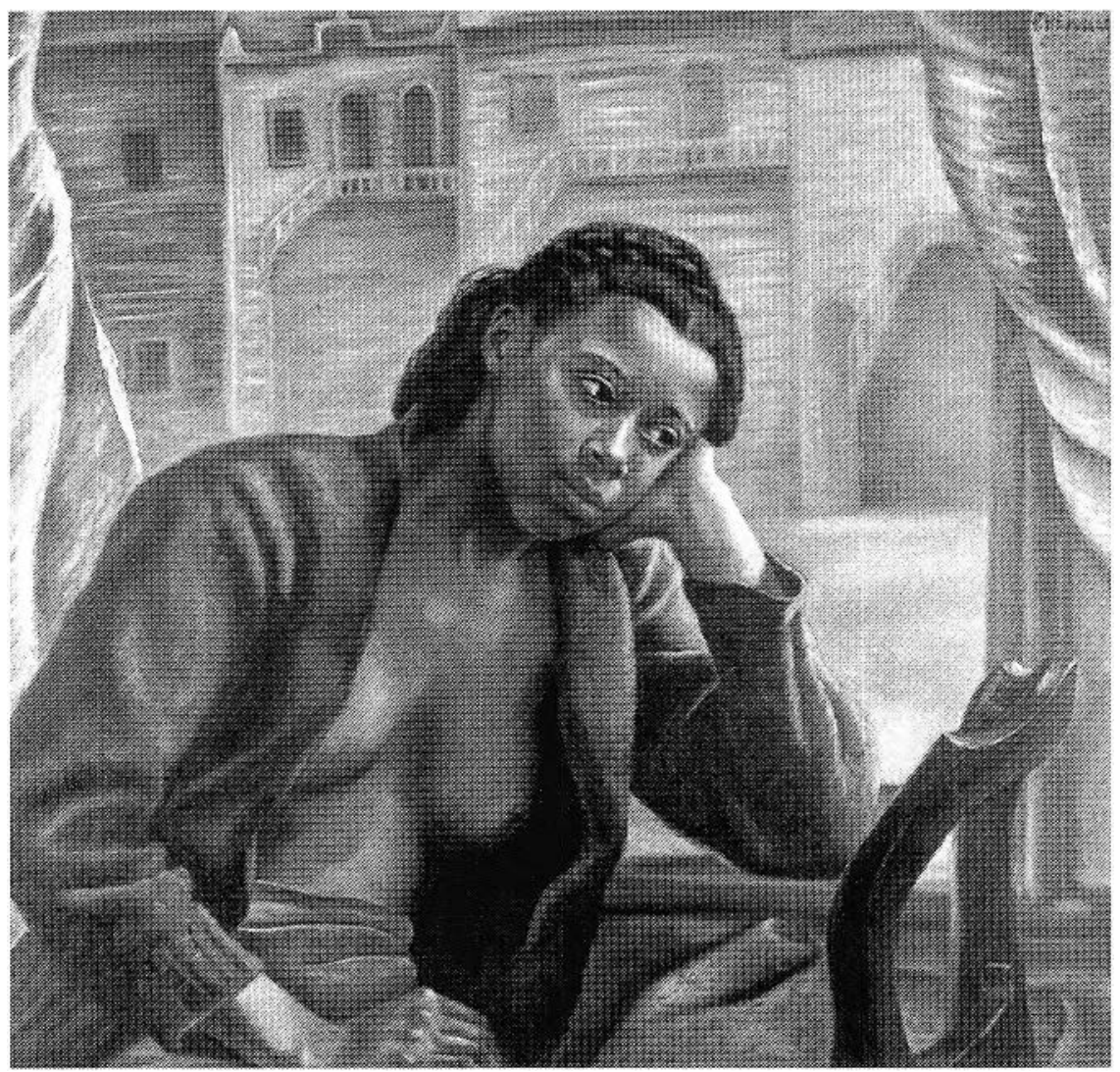

produced"? Who or what is she? And where exactly is she situated?

In the course of my research on the dynamics of text-reader relations for Feminism and the Politics of Reading, I discovered that the most effective way of conceptualizing the complex interactions of both parties was through the analysis of this shadowy (female) figure I have designated the "textual other." As the result of my own dialogues with the work of Roland Barthes, I came to realize that the "other" that readers and viewers relate to may be represented by a wide range of textual, contextual or extratextual projections. ${ }^{4}$ In other words, the women represented in Prudence Heward's paintings might be constructed as autonomous, existential subjects by some viewers, on some occasions - as when they are regarded as mimerically "real," if "fictional," characters. More often, however, they are (to invoke Barthes) "a loose collection of semes" with points of reference in the author/ artist, the model/sitter, the reader/viewer, and the reader/viewer's own "significant others." These "significant others" may, moreover, range from family relations and "objects of

verbal) that I asked the readers to consider, but limits of space meant that I had to exclude this particular set of responses from my discussion in the final version of the book. The purpose of the original exercise was to assess how, in particular, the different groups of feminist readers negotiated their responses to Heward's images of women which were both overtly and covertly coded in terms of ethnic and national identity. My questionnaire invited them to consider how the texts positioned them in this respect, as well as vis-à-vis their situation as female and feminist viewers. It also encouraged them to explore the emotional dimension of their response, in line with some of the theories I was then formulating for the central section of Feminism and the Politics of Reading, and which I shared with the groups. ${ }^{3}$ The focus of this original exercise was thus on the link berween the formal and political structuration of text-reader interaction: in particular, how readers and viewers "negotiate" their different positionings, investments and responsibilities, and who/what holds "the balance of power" in the creation of textual meaning. For the purposes of this edition of RACAR, however, I am resituating these findings within current debates concerning feminist art production. What exactly is the nature of the relationship between the female viewer and the "woman desire" to the reader's various "interpretive communities." Thought of in this way, the textual other may be radically disembodied to the extent that "she/it" becomes a discursive postioning rather than any kind of "subject" per se. Nevertheless, I have also been interested to observe how, in some of the more "anxious" readings of my respondents, the power and authority of certain interpretive communities (e.g. "the community of postcolonial scholars") are dramatically re-embodied in the readers' responses ("what would X or Y think of this interpretation?"). Yet the realization of how de-centred this textual other can become is, I believe, helpful - and perhaps cheering - for all feminist art historians trying to move beyond textual practices which focus on woman as the representational object and (as in this collection of papers) shift our attention back/towards the site(s) of production. What my own small sample of readers and viewers seems to attest is that, for them, the "woman produced" is never "simply" the woman represented on the canvas but a vast kaleidoscope of (dis)embodied subjectivities that include the artist and the artist's models alongside the subjective projections and introjections of the viewer. This will now be demonstrated with reference to a small sample of the "textual others" that my readers "discovered" in Prudence Heward's two paintings. 


\section{Textual Heroines}

It is hardly surprising that paintings as representational as Heward's should solicit readings in which viewers have responded to the "women produced" as autonomous subjects, and imagined lives and histories for them. In classic "authentic realist" manner, these existentially conceived others are then evaluated by the viewers as though they were "real people" (though, at this point, we inevitably encounter slippages from the textual heroines to significant others in the reader/viewer's own life). ${ }^{6}$ In line with the remit of the questionnaire, my readers explored their relationship with these figures in terms of both their emotional positioning (which perhaps accounts for the widespread vocabularies of desire and/or identification) and their political positioning vis-à-vis issues of national and ethnic identity. However, as I have argued in Feminism and the Politics of Reading, it is often extremely difficult for readers/viewers to do these very different types of "work" simultaneously.

Across my reader-sample as a whole, "Rollande" proved a much more popular and unproblematic textual heroine than the woman featured in Girl at a Window, although the readers went much further in constructing a narrative identity for the latter. For many readers, Rollande was conceived as a woman of fortitude and power whom, as feminist readers, they responded to with a mixture of admiration and (mostly identificatory) desire. For example:

It's refreshing to see a woman with power of her own and not nude or sexualized ... [it] inspires my determination to stand like that in place (of beliefs, desires, etc.) ... she's so solid, tough. [U: Montréal]

I feel drawn in by this picture. She is a tough, intriguing object. Looking at me, and yer looking away simultaneously. Proud of her imprisonment. She frightens me. Yer there is something comforting in the starched folds of her apron. I feel empathy for her hard fight. [F: Toronto]

I really responded to the strength of this image, to the stark full-face pose, to the blocking move in relation to space, the territorial stance, so unlike most representations of women in landscape/space. That pose is just so strong, hands on hips, no-nonsense pose. [V: Sheffield]

Very strong figure - looks like an early pioneer/settler ... I can associate myself with this figure in a romantic/emotional sort of way ... links up with childhood issues of independence, pioneering - living on a farm, raising animals, doing it all on my own. [L: Sheffield]
What these respondents have thus done is to construct a "personality" for this subject which accords with certain key signifiers they find in her formal configuration (in particular, her defiant/ defensive stance). Refracted through the discourse of feminism, this construction is then used by the viewers to negotiate and promote key aspects of their own identities in a typical mix of "desire for" and "identification with" (they are both attracted to "Rollande" and want to be her), although the latter tends (in these instances) to subsume the homoerotic connotations of the former. $^{8}$

When we turn to Girl at a Window, we find our politically aware readers and viewers much less able and willing to engage in this sort of authentic-realist response since the signifier of racial difference (the subject is black) immediately imposes itself between them and "who this 'girl' might be.") Although this reflex may, of course, be seen as a classic instance of the way in which "whiteness" is a largely unmarked and therefore supposedly "transcendent" ethnic identity, the immediate consequence for the reception of Heward's two paintings seems to be to make the discourse of postcolonialism, rather than the "woman produced," the primary textual other of this painting. This said, a number of the readers do (albeit temporarily) break through, or leave behind, their political consciences to make a more personal and humanist connection with the textual subject, mostly picking up on the "mood" she appears to be in:

I feel a vague, far-off emotional recognition of what I perceive as a lackadaisical feeling, a languorous sort of sadness, but it doesn't really strike me. [K: Toronto]

I am attracted to her, not sexually, but intellectually ... I think I know how she feels sometimes - melancholia. [F: Montréal]

I felt sad for this woman. I thought that she was very sad and tired. [C: Halifax]

Whilst, from the opposite point of view (though still responding to the subject as a realist, if fictional, character), $V$ from Sheffield observes:

I couldn't relate to the other image, Girl at a Window, as the others [in my group] could. I no longer relate to that melancholic, masochistic-almost, representation of women. I used to like that reflective pose, but particularly here, with the representation of a black woman, I don't know what's being said. [V: Sheffield]

Apart from this explicitly emotional point of contact, the other main way in which the respondents displayed their will- 
ingness/desire to "make" the subject of the painting into their textual other was through their (speculative) narrativization of her situation. Whereas the readerly construction of Rollande had depended upon the viewers asking the questions "Who is she?" and "What is she like?", the corresponding "production" of this subject elicits "What is she doing?" and the tell-tale "Where is she from?":

What is she thinking about? She seems not to care what is outside. This is about her. [F: Montréal]

What are they thinking about? Both faces bear a kind of downcast, "vacant" look. [U: Lancaster]

This "girl" looks like she is waiting for someone who is never going to come. [F: Toronto]

The whole scene is enigmatic to me. What is outside the window? Those buildings look foreign to me. I want a narrative: a clue to her story, something. There are only questions here - which may be good or bad, I suppose. [O: Montréal]

I felt it was interesting in the group, the narratives which were put upon this; exile, prostitution ... [V: Sheffield]

The second [image] has the power to evoke much more depth of feeling and fantasy and makes me almost want to construct a narrative. [L: Lancaster]

Through the combined mechanisms of emotional identification and narrativization, then, it can be seen that a number of respondents were keen to make the textual subject into their textual other by granting her a fictional autonomy which nevertheless relates directly to the perceived experiences of women (and, in this instance, black women) in the "real world." This brings me to the next category of textual others which was readily identifiable in my respondents' returns: namely, the models and their artist.

Models and Artist

Although in a minority, a few of my respondents were not content to imagine a fictional identity for the women in Heward's paintings: instead of "the woman posed," their textual other became "the woman posing." With respect to Girl at a Window, U from Montréal thus observes:

I wonder what that "real" black woman felt in Prudence
Heward's home modelling for her. If she felt it to be another servant's/housemaid's dury? ... I want to know what her life was like - to make her feel she wanted to pose for Prudence Heward? Did she get well paid? Did she have children? [U: Montréal]

Whilst this movement from the textual to the extra-textual would once have been regarded as a problematic slip in critical terms (a reader/viewer failing to attend to the "textuality" of the text), in the context of the wider politics being debated here it may be regarded as a welcome sign of viewers' resistance to reading images in isolation from their contexts of production and consumption. It is also significant and, once again, perhaps cheering, that this concern for "the woman posed" quickly connects with an interest in the the woman who posed her: in other words, the artist herself - and, even more particularly, the relationship between the two. This is seen clearly in the following extract in which the reader passes quickly from the sexual politics of the representation, to the artist (i.e. through her responsibility for what has been represented), to the model herself:

I feel frustrated at this image - her breast bare, eyes down, in a window, disconnected to the outside world; this image conveyed to me a racist assumption about African-Canadian women. I felt that she [my italics] was more than likely a domestic worker from the Islands (West Indies). [C: Halifax]

What this reading effectively does, then, is refuse the separation of text and context and force a connection between "the woman produced," her "producer," and the model (as "means of production")

When we turn back to Rollande with regard to this alternative order of textual othering, it is clear that viewers were much more inclined to think of the female subject of this painting as a "real-life" French-Canadian farm girl than as a paid sitter (i.e. Rollande is perceived to be a "portrait," whereas as Girl at a Window is not). This assumption, of course, helps to explain why they were also more inclined to respond to "Rollande" as an autonomous human subject (see discussion above) and why Prudence Heward is made a little less responsible for the woman she has "produced" (i.e. if this is a portrait, then the artist may be thought of more as a witness, and less as a conceptualizer). This is not universally the case, however. A number of respondents do feel uncomfortable with what they clearly regard as the stereotyping at work in this image, and as a consequence, Prudence Heward herself becomes - for the duration - the textual orher of their (hostile) gaze. For example: 
I felt angry - the person in the picture looks like a stereotypical image of a French farm woman ... I felt a bit disappointed because this image is still part of Canadian identity. [C: Halifax]

I feel fairly alienared by this painting. The figure doesn't look human to me - her features look entirely inhuman. Really, she appears like an alienation. That, combined with the relative starkness and boldness of the painting as a whole, makes me disbelieve its integrity somehow. She is standing in front of a typical Québeçois farmhousc and wearing traditional Habitante dress, not to mention is stocky and hearty and ruddy looking (which] makes her the epitome of the stereotype of the rustic Québeçois(e) peasant. [K: Toronto]

Yet Rollande has too much of the noble pcasant about her ... Heward's pictures cxemplify for me Canada's split vision: we know and perceive our worth and strength yet see ourselves through some colonizer or other. Hence Rollande and Girl at a Window, marvellous compositions both, still strike a rather false, sentimental note. [T: Halifax]

What all these viewers are concerned with, then, in their different ways, is the fact that the female subjects of these paintings do have their referents in the material world in the spaces/places of production, and imagining these extra-textual others (both models and their artists) becomes as important for a satisfactory "reading" of the text as exploring a relationship with the textual subject. It is an excellent example, moreover, of what really happens in the reading/viewing process: evidence of the complex relay of texual/extratextual positionings that readers adopt in order to engage and evaluate a work of art - and quite at odds with what many of them will have been trained to do.

\section{Discursive Sites}

Within the professional discourses of literary criticism and art history it has, of course, been many decades since we lost official permission either to declare the author of a text our textual other, or to make him/her responsible for the moral and ideological content of his or her work. Discourses, instead, have become the recognized target of our professional engagements, as we set out to analyse the semantic complexity of a given work. Such reading practices were, not surprisingly, strongly in evidence in my own sample of "university educated" feminist readers as they pitched into the Heward texts, and the two that I have isolated for consideration here - feminism and postcolonialism - are a clear indication not only of the way in which our professional training makes us ever ready to talk about our relationship to a given text in these terms, but also how the interpretive communities seen to be productive (and/or "policing") of these discourses displace the text as the textual other with which the reader is primarily involved.

As has already emerged in the course of the preceding discussions, the political sensitivity associated with representations of black women means that Girl at a Window interfered with the respondents' capacity for a more personal or "implicared" engagement with this text, and the discourses of feminism and postcolonialism - and their associated interpretive communities - are quickly established as the textual other with which readers have preferred to engage. ${ }^{10} \mathrm{Witness}$, for example, the following:

\section{As a feminist teacher I am concerned about representations of black women in white women's art. [L: Montréal] \\ Girl at a Window unfortunately confirms the colonial gaze that objectifies both women and people of colour. [C: Montréal]}

Girl at a Window, posed and draped like a classical model, mythologizes the impoverished prostitute. [T: Halifax]

Her head looks to the side, her eyes down, passive/submissive posc, reminds me of the Portrait of a Black Woman by Marie Guillemine Benoist (ca.1800). [U: Montréal]

Why "girl" rather than woman? [M: Halifax]

Nude woman:

- passive

- taken advantage of

- indoors = domestic sphere

- pensive, contemplative

- why is her shirt open?

- is she meant to appear overtly vulnerable or sexual?

[D: Montréal]

What all these responses are a testament to, of course, is a certain shared academic training that has enabled the readers/ viewers to "deal with" an overtly "problematic" representation of a nude woman (and this is leaving her race aside for the moment) through a "ready-made" feminist grid. These similarities of response are attributable not only to a shared training, however (though some of the Montréal group of readers were following the same undergraduate course in Art History), but also to the interlocutory pressures of the situation in which the readings were performed: namely, the fact that the participants knew they were to share their responses with other members of 
a "feminist defined" group. This is an instance, then, in which a "virtual" interpretive community of feminist scholarship is embodied in an "actual" community of friends and colleagues, most of them known to one another. In the circumstances, it is thus hardly surprising that the discourse of feminism should displace the "woman produced" as the readers' predominant textual other, and that in some instances this "other" appears to be literally re-embodied as another group member and her anticipated response (i.e. what the respondents were really engaging with was not the woman in the text but what they expected their friends to think about her!).

In the case of Rollande, we can see the same mechanisms in operation, though here there is more of a consensus that other members of the "community" will wish to read the image "on behalf of feminism." For example:

\section{As a feminist reader I find the aggressiveness of Rollande to convey the message of female empowerment. The girl gazed defiantly at the canvas, arresting any attempts of object- ification. This image speaks of female independence and determination. Rollande will not be easily swayed and there- fore provides an empowering representation for feminist art historians. [C: Montréal]}

Whilst (as some of the statements quoted in the previous sections illustrate) this sense of feminist solidarity around the signifier of "Rollande" as a "strong woman" was by no means universal, there was certainly less anxiety around the peer response to this particular image within a purely feminist context. However, as I shall now go on to discuss, a number of readers nevertheless found their relationship to the subject blocked by concerns about the colonial politics of the painting.

There is no question, indeed, that for the Canadian readers/viewers, especially, Rollande was an emotive site in terms of national and colonial politics, representing both an heroic icon and a clichéd stereotype:

Yet Rollande has too much of the noble peasant about her ... Heward's pictures exemplify for me Canada's split vision: we know and perceive our work and strength yet see ourselves through some colonizer or other. [T: Halifax]

There was some sort of cleansing, purifying dimension to the imagery - as if specific references of region, location and site had been left out in favour of typology. This scared me like the construction of pure, biological, racial types. [O: Halifax]

I am struck by the power of the figure of "Rollande" and the similarity between her forcefulness and the uncompromis- ing background. Yet the clean lines make me think of purity. [L: Montréal]

The first painting reminds me of German puritanism - of rather cold, basic and puritan values which might appeal in their simplicity - but make me want to seek out luxury. [L: Lancaster]

The woman in frowning is what I read as a slightly xenophobic manner. [U: Lancaster]

These "concerns," I suggest, are a further illustration of how a potentially more intimate and implicated relationship to the figure of the "woman produced" has been effectively usurped and replaced by a discursive positioning. Once again, it could be said that my readers are responding to the anticipated responses of their peers (with whom they knew they would go on to discuss their statements) rather than to Rollande "herself," and in this respect it is equally interesting to observe how the landscape ("background") as well as the figure are being read for signs of possible xenophobia. At this point it is worth pausing and simply reviewing the complex range of positionings viewers may thus be seen to experience with respect a single textual subject. The "woman produced" is not only multiply, but also simultaneously, experienced as: an (heroic) autonomous, human subject; the artist who "made" her; the woman who "posed" her; and now, finally, as the discursive field embodied in a particular ethnic/colonial stereotype. What it is most important to recognize here, indeed, is that as powerful as this last positioning is (the educated reader/viewer's responsibility to be disturbed by such connotations), it need not permanently override the other, more "implicated" readings. As we will see directly, "Rollande's" identity as a "pioneer woman" is elsewhere made the subject of a far more personal (and certainly less critical) response.

Needless to say, the postcolonial politics that thwarted my readers' responses to "Rollande" as a textual other also leapt to the fore in their response to the figure represented in Girl at a Window. For some the fact that this woman was not only naked (see previous discussion) but black made them feel that it was impossible to respond to the text in any way other than as a category of "problematic representation:" as L from Montréal sums up neatly: "As a feminist teacher I am concerned about representations of black women in white women's art." A similar, uncompromising, politically aware resistance is heard in the following:

Girl at a Window unfortunately confirms the colonial gaze that objectifies both woman and people of colour. [C: Montréal] 
This image conveyed to me a racist assumption about African-Canadian women. [C: Halifax]

I do not understand Girl at a Window and find perhaps some alienation because of cultural difference and difficulty "reading" the subject. [L: Sheffield]

What is interesting about this particular set of responses, meanwhile, is where the readers chose to locate the responsibility for the "making" of this problematic representation. Whilst $\mathrm{L}$ and $C$ from Montréal do, indeed, seem to situate it purely at the level of discourse, $C$ from Halifax (as we have already seen in the preceding section) directly imputes the artist, whilst L from Sheffield is prepared to take responsibility for the problem herself.

This last point inevitably leads us on to a new level of complexity with respect to textual othering. Whilst I began this section by suggesting how, in certain instances, the exigencies of a reader's interpretive community and its associated discourses (e.g. feminism, postcolonialism) will cause her to deflect her attention from the "other" in the text to the "others" in that community, we can also see that such discursive awareness is not necessarily an end in itself, but might - as with C from Halifax - act as the springboard for "second-degree" othering. In practice, the line of readerly activity may thus go something like this:

(1) Viewer sees representation of black woman in painting which rings immediate warning bells around issues of representation.

(2) Viewer figures a response which corresponds with the discursive positioning of her interpretive community. The interpretive community thus becomes her immediate textual other, displacing the representation of the woman in the text.

(3) The critical discourses endorsed by the interpretive community permit a number of ways with dealing with the text. One of these is "author responsibility." The reader thus chooses to make the author the subject of her engagement, and she replaces the interpretive community as the reader's most immediate textual other.

It is, I would argue, only by attending to these fluctuating alignments within the reading/viewing process that we can fully appreciate how complex a process it is: in particular, how each of the positionings I have described here so far can be - as far as the reader's experience is concerned - both simultaneous and consequent upon one another. Thus, "the woman produced" is rarely a fixed or single site, even when a particular positioning (e.g. the discourses of feminism and postcolonialism invoked by this particular example) would seem to obstruct or overrule any other response.

\section{Significant Others}

It is to underline this last point that I have chosen to conclude this article by looking at the type of textual othering that we might well expect our academic interpretive communities to delegitimate: our projection upon the "woman produced" of our own "significant others" in an uncompromising displacement of "text" by (a personally inflected) "context." Despite the fact that the majority of my readers were clearly acutely aware of the way in which the discourses of feminism and postcolonialism were urging them to view these images, a number of Canadian participants nevertheless threw themselves headlong into this problematic political arena by a readerly manoeuvre that associated the figure of Rollande with their own mothers and grandmothers:

I felt the person in the picture could be my granny or great granny; [it] made me feel proud of my French background. [C: Halifax]

In terms of my autobiography, my mother was raised on a farm out west around the same period. I am attracted to this past, buc considering the French/English strife in Canada, I feel a bit uncomfortable and feel I cannot identify because I am English. [L: Montréal]

Rollande reminds me of a photograph of my grandmother at the same age: large and serviceable and plain as the house itself; formidable even when exhausted. What weight on their far more fortunate grandaughters: how to honour them but by fulfilling all possibilities! Yet Rollande has too much of the noble peasant about her. [U: Halifax]

What we see in this last extract is that, despite the caveat of the final sentence ("Rollande has too much of the noble peasant about her"), the reader is compelled to relate to the figure through one of her own "significant others." At the same time, then, that she is "preparing" the response that the members of her immediate (and virtual) academic community will expect to hear, so is she also making a connection that directly aligns her family and herself with those colonizing powers. For a moment, indeed, the emotions raised by pride in, and loyalty to, her own "pioneering family," cause her to suspend her wider political judgement. Or, to figure it the way I did in Feminism and the Politics of Reading, she is simply too "implicated" in the text to achieve a hermeneutic perspective on it. What we consequently end up with is a prototypically "split" reader-response in which 
the "woman produced" (the textual other to whom the reader/ viewer relates) is both the extra-textual configuration of her grandmother (and, by extension, herself) and a member of her interpretive community (embodied, perhaps, in a particular friend or colleague). A similar splitting is evident in the comment from $\mathrm{L}$ of Montréal, although here the projection of her own significant family "other" onto "Rollande" is instantaneously blocked by an awareness of her own "Englishness" (an awareness produced by the pressures of her social as well as her academic positioning).

Yet - no matter how strongly (and legitimately) circumscribed by political concerns - there is, I feel, a case for looking positively at these readings in which textual subjects become the springboard for various extratextual associations. While there might be little space in academic criticism for indulging such readerly fantasies, it is undeniable that all of us engage in such practices, and in the context of the present special issue of $R A C A R$, it might be presented as a further re-assurance that the "woman produced" within the traditions of Western Art can never simply be reduced to a "representational object" or an "intertextual site." By finding traces of mothers, lovers, mentors, and/or (by extension) themselves in such images, the women viewers may be said to be engaging in a creative activity which is comparable to that of the artist itself, as is especially evident in these written responses. Prudence Heward's portrait of a Québeçoise farm girl may thus become the springboard for another, parallel story, as is evidenced in this strikingly imaginative "reconstruction" by V of Sheffield:

Rollande: I really responded to the strength of this image, to the stark full-faced pose, to the blocking move in relation to space, the territorial stance, so unlike most representations of women in space ... My [own] relation to space has changed so much in the last year, and this painting seems to crystallize this. The house is so separate - denotes self-sufficiency. This is not my situation, it's a very specific setting with a set of meanings which are not mine ... But whilst it's not directed at me, it still means for me. That sense of being in an isolated situation, i.e. far from people and amenities, means that you have to be self-reliant. That means some struggle, but the relation to land is worth it. I don't feel any fear in this space; I don't lock doors - I walk out at night; I'm not worried on my own. This is a woman not exactly at ease with the landscape - she's not smiling at all. But she is there, without fear, and she has a working relationship to it. [V: Sheffield]

Especially notable here, I feel, is the constant slippage between "Rollande" and the reader - to the extent that, by the end of "the story," it is not clear at all who "she" is ("Rollande"? The reader? The reader's "significant other"?). What is clear is that, in the process of her engagement, $\mathrm{V}$ has herself become "author" of a text that is new and separate from Heward's: she is now the "woman producer" and not the readerly version of "the woman produced."

\section{Conclusion}

What we might conclude, then, is that through the range of "textual otherings" guaranteed in any reading/viewing "event," the "woman produced" will always escape the formal and ideological limits that the act of representation seeks to impose upon her. Whilst recent critical practice may, indeed, have worked to hyper-textualize such images and move them ever further from the site of their production, this is not the "reality" of the reading process in which viewers may be seen to be engaged in a constant relay between the text and its extratextual referents, including the artist, her models and the readers' own "significant others." Whilst this discovery does not, in itself, obviate the urgent need for more work on women's artistic production in the field of feminist art history, it may perhaps offer some consolation to those (including many of the contributors to this special issue!) who have become depressed and wearied by what appears to be an endless reification/deification of the "woman produced." The evidence, albeit from this small survey, is that readers - including academic/professionally trained readers - are far more "implicated" in both the text and its production than has previously been allowed. This means that the engagement of the female viewer with the female subjects of texts like Prudence Heward's can create a powerful and imaginative dialogue between artist and viewer. Both artist and viewers, in effect, become "producers." By using their own, complex textual and extra-textual positionings to (re)imagine the women represented, these viewers effectively mimic and recreate the circumstances of the text's (first) production in which the "woman produced" - whatever she is or is not - is certainly more than the sum total of either her formal or ideological parts.

\section{Notes}

I would like to acknowledge the considerable time and effort expended by all the (anonymized) participants in my Reader Survey, namely: Allyson Adley, Sarita Emelianna Ahouja, Melissa Branicky, Jan Carder, Sarah Franklin, Karen Grandy, Anne-Marie Grant, Jill LeBihan, Celia Lury, Jill McKenna, Maureen McNeil, Sara Mills, Ilya Parkins, Tessa Perkins, Jacqueline Reid-Walsh, Beverley Skeggs, Donald R.Spencer, Jackie Stacey, Adrienne Trucchi, Abbie Weinburg and Rhoda Zuk. Thanks also to Professor Janice Helland and staff and students at Concordia University, Montréal, for supporting the project at different stages, and to Barbara Meadowcroft, Fellow of the Simone de Beauvoir Institute, for introducing me to the work of Prudence Heward. 
1 The most comprehensive account of Prudence Heward's life and work to date is the exhibition catalogue by Natalie Luckyj, The Art of Expressions of Will: Prudence Heward, exh. cat., Kingston, Agnes Etherington Art Centre (Kingston, Ont., 1986).

2 Lynne Pearce, Feminism and the Politics of Reading (London, 1987).

3 The five groups were based in educational establishments in Canada (Montréal, Halifax and Toronto) and in the U.K. (Lancaster and Sheffield), and each group comprised between four and six members, some of whom were known to each other before the exercise, and some of whom were not. They represented women (and one man) at different stages of their educational careers, and also a fairly broad range of age and culcural diversity: my only requirement regarding their participation was that they identified themsclves as "feminist." For a full-length discussion of the methodology associated with this research, see Pearce, Feminism and the Politics of Reading, 220-25. It should also be noted that the texts of the participants included here are merely extracts from much longer statements, and also that I have quoted from the same text - for different purposes - on more than one occasion.

4 On the "Textual Other," see Roland Barthes, A Lover's Discourse: Fragments, trans. Richard Howard (Harmondsworth, 1978) and also chapters five and six of Pearce, Feminism and the Politics of Reading.
5 The concept "interpretive community" was famously coined by Stanley Fish in Is there a Text in this Class? The Authority of Interpretive Communities (Cambridge, MA, and London, 1980) which refers to the way in which our acts of readerly interpretation depend crucially upon the context in which they are received and, in particular, the authority of our immediate peer groups.

6 For a full account of "authentic realism" as a type of reading practice and its feminist implications, see chapter two, by Sara Mills, in Lynne Pearce and Sara Mills, eds, Feminist Readings / Feminists Reading, 2nd edn (Hemel Hempstead, 1996), 56-90.

7 Pearce, Feminism and the Politics of Reading, 243-49.

8 Pearce, Feminism and the Politics of Reading, 243.

9 It should be noted that this awareness was evident in the responses by boch white and black members of the groups, although the implications were obviously different in terms of their subsequent self-positioning as readers.

10 The concept of "implicated reading" is central to the alternative models of reading that I investigate in Pearce, Feminism and the Politics of Reading. Here it is contrasted, in particular, with the "hermeneutic" practices ("reading in search of meaning") in which we engage as professional readers and critics. "Implication" here implies both a more involuntary and a more "emotional" engagement with a text via its various "textual others." 